\title{
ANALISA TINGKAT PENERIMAAN APLIKASI SCRATCH MENGGUNAKAN TECHNOLOGY ACCEPTANCE MODEL (TAM)
}

\author{
Goldie Gunadi $^{1}$, I Ketut Sudaryana ${ }^{2}$ \\ 1,2Teknik Informatika \\ ${ }^{1,2}$ Sekolah Tinggi Manajemen Informatika dan Komputer (STMIK) Widuri Jakarta, Indonesia \\ Correspondence email: send2goldie@ gmail.com
}

Article history: $\quad$ Submission date: Juni 3, $2021 \quad$ Revised date: Juni 14, $2021 \quad$ Accepted date: Juni 30, 2021

\begin{abstract}
In connection with the need for making instructional media applications by teachers in the distance learning process, PT. Bangun Satya Wacana (BSW) through the Diginusa department held training on the use of the Scratch visual programming application to create learning materials such as games, animations and interactive quizzes. Scratch is a graphical programming language using drag and drop command blocks. Besides that, Scratch can be used both online and offline, so it is very helpful for the distance learning process $(D L P)$. This research aims to see how the level of acceptance of teachers to Scratch using the Technology Acceptance Model (TAM) method. The indicators measured are Self-Efficacy, Complexity, Perceived Usefulness, Perceived Ease of Use, Intention to Use and Actual Technology Use, then analyzed by linear regression method with the help of IBM SPSS software. From the results of the analysis carried out, it can be seen that the Intention to Use affects the Actual Technology Use. Perceived Usefulness and Perceived Ease of Use together affect the Intention to Use. Perceived Ease of Use, Self-Efficacy and Complexity together have a significant effect on Perceived Usefulness.
\end{abstract}

Keywords: Technology Acceptance Model, TAM, Scratch, Linier Regression

\begin{abstract}
ABSTRAK
Sehubungan dengan adanya kebutuhan terhadap pembuatan aplikasi media pembelajaran oleh para guru dalam proses pembelajaran jarak jauh, PT. Bangun Satya Wacana (BSW) melalui departemen Diginusa menyelenggarakan pelatihan penggunaan aplikasi pemograman visual Scratch untuk membuat materi pembelajaran seperti games, animasi dan kuis interaktif. Scratch merupakan bahasa pemrograman yang berbasis grafik dengan memanfaatkan balok-balok perintah dengan metode drag and drop (Bahar, 2019). Disamping itu, Scratch dapat digunakan baik secara online maupun offline, sehingga sangat membantu untuk proses pembelajaran jarak jauh (PJJ). Penelitan ini bertujuan untuk mengetahui bagaimana tingkat penerimaan dari para guru terhadap Scratch dengan menggunakan metode Technology Acceptance Model (TAM). Indikator yang diukur adalah Efikasi Diri, Kerumitan, Persepsi Kegunaan, Persepsi Kemudahan Penggunaan, Intensi Penggunaan dan Penggunaan Teknologi Sesungguhnya kemudian dianalisis dengan metode regresi linier dengan bantuan perangkat lunnak IBM SPSS. Dari hasil analisis yang dilakukan dapat diketahui bahwa Intensi Penggunaan berpengaruh terhadap Penggunaan Teknologi Sesungguhnya. Persepsi Kegunaan dan Persepsi Kemudahan Penggunaan secara bersama-sama berpengaruh terhadap Intensi Penggunaan. Persepsi Kemudahan Penggunaan, Efikasi Diri dan Kerumitan secara bersama-sama berpengaruh yang cukup signifikan terhadap Persepsi Kegunaan.
\end{abstract}

Kata Kunci: Technology Acceptance Model, TAM, Scratch, Regresi Linier

\section{PENDAHULUAN}

Diginusa adalah Departemen dari PT. Bangun Satya Wacana (BSW) yang berdiri sejak tahun 1989, perusahaan penyedia kurikulum pendidikan dan sistem integrator di sekolah mulai dari TK hingga SMA / SMK (PT Bangun Satya Wacana, n.d.). BSW memiliki pengalaman panjang dan pelanggan yang loyal. Produk BSW mencakup kurikulum ICT (Information \& Communcation Technology) modern yang sudah digunakan di sekolah - sekolah swasta mulai dari Medan, Bengkulu, Riau, Pekanbaru, Palembang, Lampung, Jabodetabek, Banjarmasin, Balikpapan, Jawa Tengah, Jawa Timur, Manado, Ambon, dan Manokwari. 
Misi utama Diginusa adalah mencerdaskan anak bangsa melalui solusi pembelajaran bebasis digital yang inovatif, efektif, dan bermutu. Diginusa sebagai sumber belajar digital diharapkan dapat menjadi solusi yang tepat bagi sekolah untuk menghadapi tantangan dunia pendidikan era digital. Teknologi hadir justru menambah daya kreativitas sekolah baik guru maupun siswa untuk menerapkan pola pendidikan yang baru.

Semenjak wabah virus Covid-19 menyebar di seluruh penjuru dunia, termasuk Indonesia, metode pembelajaran berubah signifikan dari yang sifatnya tatap muka, menjadi pembelajaran jarak jauh (PJJ) dengan memanfaatkan teknologi informasi (Suharwoto, 2020). Hal ini mengakibatkan setiap guru harus mampu menyusun atau membuat materi pembelajaran yang dapat diajarkan secara daring, dengan memperhatikan dukungan perangkat yang dimiliki oleh siswa. Untuk memenuhi kebutuhan tersebu, Scratch merupakan salah satu alternatif perangkat lunak yang digunakan oleh para guru. Scratch merupakan bahasa pemrograman yang berbasis grafik, sangat berbeda dengan bahasa pemrograman yang berbasis teks, yang sangat membutuhkan ketelitian karena berkaitan erat dengan penulisan sintaks. Scratch memanfaatkan balok-balok perintah dengan metode drag and drop. Disamping itu, Scratch dapat digunakan baik secara online maupun offline, sehingga sangat membantu untuk proses pembelajaran jarak jauh (PJJ).

Melihat kondisi ada, maka Diginusa sebagai Lembaga yang bergerak dalam bidang pendidikan teknologi informasi dan komunikasi (TIK) dari tingkat TK, SD, SMP dan SMA, menyelenggarakan pelatihan bagi guru, khusus materi bagaimana menggunakan aplikasi pemograman visual Scratch untuk membuat materi pembelajaran seperti games, animasi dan kuis interaktif (Susanto, 2019). Penelitian yang dilakukan ini bertujuan untuk mengetahui seberapa jauh penerimaan guru terhadap teknologi perangkat lunak Scratch untuk membuat bahan ajar yang efektif dalam proses pembelajaran jarak jauh (PJJ). Metode pengukuran yang digunakan dalam penelitian adalah Technology Acceptance Model (TAM).

Pada penelitian sebelumnya yang dilakukan oleh Saras Mareta Ratri dengan judul: Analisis Faktor-Faktor Yang Memengaruhi Penggunaane-Learning Moodle Oleh Guru Smk Negeri 2 Yogyakarta Dengan Pendekatan Technology Acceptance Model (TAM), dilakukan penelitian untuk mengetahui faktor yang memengaruhi penggunaan e-learning berbasis Moodle oleh guru SMK Negeri 2 Yogyakarta. E-Learning yang diteliti adalah portal e-learning milik SMK Negeri 2 Yogyakarta, yaitu PINTER. Tujuan tersebut dicapai dengan menjelaskan pengaruh variabel eksternal yaitu $e$ learning self-efficacy, kerumitan dan keterbatasan waktu terhadap variabel-variabel dalam kerangka Technology Acceptance Model (TAM).(Budiarti \& Risyanto, 2020).
Tujuan dari penelitian ini adalah untuk mengetahui bagaimana tingkat penerimaan guru terhadap teknologi perangkat lunak Scratch sebagai alat untuk pembuatan aplikasi media pembelajaran. Dan dapat dijadikan sebagai bahan untuk evaluasi proses pelatihan yang dilakukan oleh PT. Bangun Satya Wacana (BSW) sebagai upaya untuk meningkatkan kemampuan dan keterampilan guru dalam penyelenggaraan metode pembelajaran jarak jauh.

\section{METODE PENELITIAN}

Technology Acceptance Model (TAM)

Technology Acceptance Model (TAM) yang juga disebut dengan Model Penerimaan Teknologi merupakan salah satu teori tentang penggunaan sistem teknologi informasi yang dianggap sangat berpengaruh dan umumnya digunakan untuk menjelaskan penerimaan individual terhadap penggunaan sistem teknologi informasi (HM, 2008).

TAM diperkenalkan pertama kali oleh Fred Davis pada tahun 1986 dan merupakan pengembangan dari Theory of Reasoned Action (TRA), yang dikembangkan oleh Fishbein dan Ajzen pada 1980 (Nikola Marangunić \& Andrina Granić, 2015).

Telah terjadi beberapa revisi terhadap model yang diusulkan. Berikut adalah versi terakhir yang dikembangkan oleh Venkatesh \& Davis pada tahun 1996 (D.Davis \& Venkatesh, 1996).

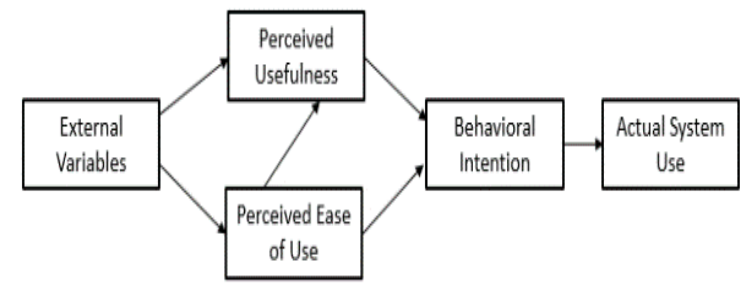

Sumber : (D.Davis \& Venkatesh, 1996)

Gambar 1. Model TAM oleh Venkatesh \& Davis

\section{Konstruksi TAM}

Berikut adalah konstruksi TAM yang digunakan dalam penelitan ini:

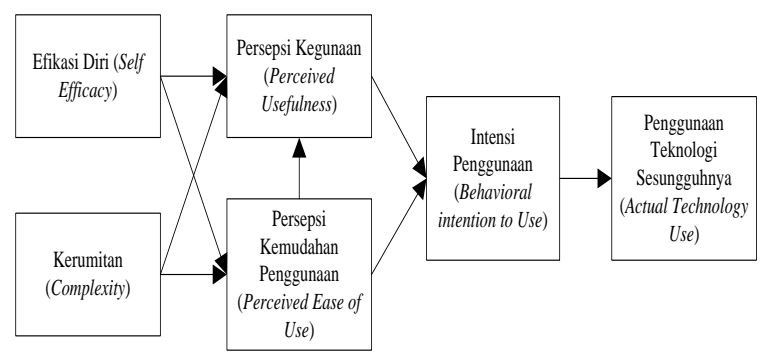

Sumber : (Goldie Gunadi \& Sudaryana, 2020) Gambar 2. Konstruk TAM Penelitian 
1. Efikasi Diri (Self-Efficacy)

Efikasi Diri menggambarkan keyakinan dan kemampuan guru dalam menggunakan Scratch dalam pembuatan aplikasi media pembelajaran.

2. Kerumitan (Complexity)

Menggambarkan komplesitas atau kesulitan yang dialami oleh guru dalam penggunaan Scratch.

3. Persepsi Kegunaan (Perceived Usefulness)

Menggambarkan sejauh mana guru dapat menganggap penggunaan Scratch akan dapat meningkatkan performa atau kualitas pekerjaannya.

4. Persepsi Kemudahan Penggunaan (Perceived Ease of Use)

Menggambarkan sejauh mana guru merasa sangatlah mudah untuk menggunakan Scratch sehingga tidak memerlukan usaha yang berarti.

5. Intentsi Penggunaan (Behavioral intention to Use) Menggambarkan niat atau motivasi guru untuk menggunakan Scratch untuk membuat media pembelajaran.

6. Penggunaan Teknologi Sesungguhnya (Actual Technology Use)

Menggambarkan perilaku nyata guru untuk menggunakan Scratch sebagai suatu teknologi perangkat lunak yang dapat menunjang proses kegiatan pembelajaran jarak jauh.

\section{Metode Pengumpulan Data}

Sumber data penelitian merupakan sumber data primer berupa jawaban responden terhadap pernyataan dalam kuesioner, dan sumber data sekunder meliputi daftar guru, profil perusahaan PT. Bangun Satya Wacana (BSW) dimana didalamnya terdapat Diginusa sebagai salah satu departemen tempat dilakukannya penelitian ini.

Responden terdiri dari 8 orang guru yang telah mengikuti pelatihan pembuatan aplikasi media pembelajaran menggunakan Scratch yang diadakan oleh Diginusa.

Kuesioner diukur dengan menggunakan skala Likert dengan level 1 sampai 5 (Aprilia \& Ghozali, 2013).

\begin{tabular}{cl} 
& Tabel 1. Skala Likert \\
\hline Nilai & \multicolumn{1}{c}{ Keterangan } \\
\hline 5 & Sangat Setuju (SS) \\
4 & Setuju (S) \\
3 & Ragu-ragu/ Netral (R) \\
2 & Tidak Setuju (TS) \\
1 & Sangat Tidak Setuju (STS) \\
\hline Sumber : (Goldie Gunadi \& Sudaryana, 2020)
\end{tabular}

Metode Analisa Data

Analisa data penelitian dilakukan dengan menggunakan bantuan program IBM SPSS Statistics.
1. Uji Validitas

Uji validitas digunakan untuk mengetahui seberapa cermat suatu item dalam mengukur apa yang ingin dikukur.

Teknik uji validitas dengan menggunakan korelasi Pearson dengan cara mengorelasikan skor item dengan skor total item setiap variable. Pengujian signifikansi dilakukan pada tingkat signifikansi 0,05 dengan uji 2-sisi. Sebuah item dinyatakan tidak valid apabila nilai $r$ hitung (Pearson Correlation) kurang dari nilai $r$ tabel dan nilai signifikansi lebih besar dari 0,05 (Duwi Priyatno, 2018).

2. Uji Reliabilitas

Uji reliabilitas digunakan untuk mengetahui konsistensi alat ukur yang menggunkan kuesioner. Metode yang digunakan dalam penelitian untuk mengukur skala rentangan adalah Cronbach's Alpha (Duwi Priyatno, 2018).

Menurut Sekaran reliabilitas kurang dari 0,6 dianggap kurang baik, 0,7 dapat diterima dan diatas 0,8 adalah baik (Sekaran, 2006).

3. Analisis Regresi Linier Berganda

Analisis regresi linier berganda adalah analisis untuk mengetahui ada tidaknya pengaruh yang signifikan secara parsial atau simultan antara dua atau lebih variable independen terhadap sebuah variable dependen. Selain itu juga untuk mengetahui bagaimana dan seberapa besar pengaruhnya serta untuk memprediksi nilai variabel dependen dengan menggunakan variabel independen (Duwi Priyatno, 2018).

Persamaan regresi linier berganda dengan 2 variabel independen :

$$
Y=a+b_{1} X_{1}+b_{2} X_{2}+e
$$

Persamaan regresi linier berganda dengan 3 variabel independen :

$$
\begin{aligned}
& Y=a+b_{1} X_{1}+b_{2} X_{2}+b_{3} X_{3}+e \\
& \mathrm{Y} \text { : Nilai variable dependen } \\
& \text { a : Konstanta, yaitu jika } X_{1}, X_{2} . . X_{n}=0 \\
& b_{1 . . n} \text { : Koefisien regresi, yaitu nilai } \\
& \text { peningkatan atau penurunan variable } \mathrm{Y} \\
& \text { yang didasarkan variabel } \mathrm{X}_{1}, \mathrm{X}_{2} . . \mathrm{X}_{\mathrm{n}} \\
& \mathrm{X}_{1 . . \mathrm{n}} \text { : Variabel independen } \\
& \text { e : Error (diasumsikan nilai 0) }
\end{aligned}
$$

\section{Uji F}

Uji $F$ atau uji koefisien regresi digunakan untuk mengetahui apakah variabel independen berpengaruh secara signifikan terhadap variabel dependen (Duwi Priyatno, 2018).

Pengujian dilakukan dengan menggunakan tingkat signifikansi 0,05 yang artinya peluang untuk memperoleh kesalahan maksimal sebesar 5\%, atau dengan kata lain 95\% keputusan adalah benar. 


\section{Uji t}

Uji t atau uji regresi secara parsial digunakan untuk mengetahui apakah secara parsial variabel independen berpengaruh signifikan terhadap variabel dependen (Duwi Priyatno, 2018).

Pengujian dilakukan dengan menggunakan tingkat signifikansi 0,05 dan uji 2 sisi.

\section{HASIL DAN PEMBAHASAN}

Demografi Responden

Berdasarkan usia responden, sebagian besar responden berusia antara 30 hingga kurang dari 35 tahun, yakni sebanyak 3 orang atau 37,5\% dari total responden.

Tabel 2. Distribusi Usia Responden

\begin{tabular}{crrrr}
\hline Usia & $\begin{array}{c}\text { Freque } \\
\text { ncy }\end{array}$ & Percent & $\begin{array}{c}\text { Valid } \\
\text { Percent }\end{array}$ & $\begin{array}{c}\text { Cumulative } \\
\text { Percent }\end{array}$ \\
\hline $25-<30 \mathrm{Th}$ & 2 & 25,0 & 25,0 & 25,0 \\
$30-<35 \mathrm{Th}$ & 3 & 37,5 & 37,5 & 62,5 \\
$35-<40 \mathrm{Th}$ & 1 & 12,5 & 12,5 & 75,0 \\
$40-<45 \mathrm{Th}$ & 1 & 12,5 & 12,5 & 87,5 \\
$45-<50 \mathrm{Th}$ & 1 & 12,5 & 12,5 & 100,0 \\
\hline
\end{tabular}

Sumber : (Goldie Gunadi \& Sudaryana, 2020)

Berdasarkan jenis kelamin responden, sebagian besar responden adalah perempuan, yakni sebanyak 5 orang atau $62,5 \%$ dari total responden.

Tabel 3. Distribusi Jenis Kelamin Responden

\begin{tabular}{lrrrr}
\hline $\begin{array}{c}\text { Jenis } \\
\text { Kelamin }\end{array}$ & $\begin{array}{c}\text { Freque } \\
\text { ncy }\end{array}$ & Percent & $\begin{array}{c}\text { Valid } \\
\text { Percent }\end{array}$ & $\begin{array}{c}\text { Cumulative } \\
\text { Percent }\end{array}$ \\
\hline Laki-laki & 3 & 37,5 & 37,5 & 37,5 \\
Perempuan & 5 & 62,5 & 62,5 & 100,0 \\
\hline
\end{tabular}

Sumber : (Goldie Gunadi \& Sudaryana, 2020)

Berdasarkan tingkat pendidikan akhir responden, responden memiliki tingkat pendidikan akhir D-3 dan S1 , yakni masing-masing sebanyak 4 orang atau $50 \%$ dari total responden.

Tabel 4. Distribusi Pendidikan Akhir Responden

\begin{tabular}{lrrrr}
\hline Pendidikan & $\begin{array}{c}\text { Freque } \\
\text { ncy }\end{array}$ & Percent & $\begin{array}{c}\text { Valid } \\
\text { Percent }\end{array}$ & $\begin{array}{c}\text { Cumulative } \\
\text { Percent }\end{array}$ \\
\hline D-3 & 4 & 50,0 & 50,0 & 50,0 \\
S-1 & 4 & 50,0 & 50,0 & 100,0 \\
\hline
\end{tabular}

Sumber : (Goldie Gunadi \& Sudaryana, 2020)

Berdasarkan latar belakang pendidikan akhir responden, sebagian besar responden memiliki latar belakang pendidikan di bidang komputer, yakni sebanyak 3 orang atau 37,5\% dari total responden.

Tabel 5. Distribusi Latar Belakang Pendidikan Responden

\begin{tabular}{lrrrr}
\hline $\begin{array}{c}\text { Latar } \\
\text { Belakang }\end{array}$ & $\begin{array}{c}\text { Freque } \\
\text { ncy }\end{array}$ & Percent & $\begin{array}{c}\text { Valid } \\
\text { Percent }\end{array}$ & $\begin{array}{c}\text { Cumulative } \\
\text { Percent }\end{array}$ \\
\hline Sosial & 1 & 12,5 & 12,5 & 12,5 \\
Ekonomi & 1 & 12,5 & 12,5 & 25,0 \\
\hline
\end{tabular}

\begin{tabular}{llllr}
\hline $\begin{array}{l}\text { Kompute } \\
\mathrm{r}\end{array}$ & 3 & 37,5 & 37,5 & 62,5 \\
Lainnya & 3 & 37,5 & 37,5 & 100,0 \\
\hline
\end{tabular}

Sumber : (Goldie Gunadi \& Sudaryana, 2020)

Variabel dan Indikator Penelitian

Tabel 6. Variabel dan Indikator TAM

\begin{tabular}{|c|c|c|c|}
\hline \multirow{2}{*}{$\begin{array}{c}\text { Uru } \\
\mathbf{t}\end{array}$} & \multirow[t]{2}{*}{ Variabel } & \multicolumn{2}{|r|}{ Indikator } \\
\hline & & $\begin{array}{c}\text { Kod } \\
\text { e }\end{array}$ & Nama Indikator \\
\hline \multirow[t]{4}{*}{1} & Efikasi Diri & I.1-1 & Kepercayaan diri \\
\hline & (Self & I.1-2 & Keterampilan dan keahlian \\
\hline & Efficacy) & I.1-3 & Motivasi \\
\hline & & I.1-4 & Minat \\
\hline \multirow[t]{2}{*}{2} & Kerumitan & I. $2-1$ & Kesulitan implementasi \\
\hline & (Complexity & I.2-2 & Kompleksitas fitur \\
\hline \multirow[t]{3}{*}{3} & Persepsi & I.3-1 & Meningkatkan produktivitas \\
\hline & $\begin{array}{l}\text { Kegunaan } \\
\text { (Perceived }\end{array}$ & I. $3-2$ & $\begin{array}{l}\text { Meningkatkan efektivitas dan } \\
\text { kualitas }\end{array}$ \\
\hline & Usefulness) & I.3-3 & Kelengkapan fitur \\
\hline \multirow[t]{5}{*}{4} & Persepsi & I.4-1 & Mudah dipelajari \\
\hline & Kemudahan & I.4-2 & Mudah digunakan \\
\hline & Penggunaan & I.4-3 & Fleksibel \\
\hline & (Perceived & I.4-4 & Kemudahan instalasi \\
\hline & Ease of Use) & I.4-5 & Kemudahan mencapai tujuan \\
\hline \multirow[t]{3}{*}{5} & Intensi & I.5-1 & Keinginan menggunakan \\
\hline & $\begin{array}{l}\text { Penggunaan } \\
\text { (Behavioral }\end{array}$ & I.5-2 & $\begin{array}{l}\text { Rencana untuk tetap } \\
\text { menggunakan di masa datang }\end{array}$ \\
\hline & $\begin{array}{l}\text { intention to } \\
\text { Use) }\end{array}$ & I.5-3 & $\begin{array}{l}\text { Mengajak pihak lain untuk } \\
\text { menggunakan }\end{array}$ \\
\hline \multirow[t]{3}{*}{6} & $\begin{array}{l}\text { Penggunaan } \\
\text { Teknologi }\end{array}$ & I.6-1 & $\begin{array}{l}\text { Penggunaan untuk kebutuhan } \\
\text { ril }\end{array}$ \\
\hline & Sesungguhn & I.6-3 & Kepuasan \\
\hline & $\begin{array}{l}\text { ya (Actual } \\
\text { Technology } \\
\text { Use) }\end{array}$ & I.6-4 & Manfaat bagi pihak lain \\
\hline
\end{tabular}

Indikator Penelitian dan Pernyataan Kuesioner

Tabel 7. Indikator dan Pernyataan Kuesioner

\begin{tabular}{|c|c|c|}
\hline $\begin{array}{l}\text { Indika } \\
\text { tor }\end{array}$ & $\begin{array}{c}\text { Kode } \\
\text { Pernya } \\
\text { taan }\end{array}$ & Pernyataan \\
\hline I.1-1 & P.1.1 & $\begin{array}{l}\text { Saya memiliki kepercayaan diri dalam } \\
\text { penggunaan teknologi }\end{array}$ \\
\hline I.1-2 & P.1.2 & $\begin{array}{l}\text { Saya memiliki pengalaman menggunakan } \\
\text { aplikasi sejenis untuk membuat media } \\
\text { pembelajaran }\end{array}$ \\
\hline I. $1-3$ & P.1.3 & $\begin{array}{l}\text { Saya memiliki motivasi untuk mempelajari } \\
\text { teknologi pembuatan media pembelajaran }\end{array}$ \\
\hline I. 1-4 & P.1.4 & $\begin{array}{l}\text { Saya memiliki minat dalam penguasaan } \\
\text { teknologii pembuatan media pembelajaran }\end{array}$ \\
\hline \multirow[t]{3}{*}{ I. $2-1$} & P. 2.1 & $\begin{array}{l}\text { Saya mengalami kesulitan untuk } \\
\text { mempublikasikan hasil media pembelajaran } \\
\text { yang sudah dibuat ke pengguna melalui } \\
\text { aplikasi kelas virtual seperti Google } \\
\text { Classroom }\end{array}$ \\
\hline & P. 2.2 & $\begin{array}{l}\text { Saya kesulitan dalam mengintegrasikan } \\
\text { SCRATCH dengan aplikasi-aplikasi }\end{array}$ \\
\hline & & $\begin{array}{l}\text { pendukung lainnya yang biasa saya } \\
\text { gunakan }\end{array}$ \\
\hline I. $2-2$ & P. 2.3 & $\begin{array}{l}\text { Saya merasa fitur-fitur yang disediakan } \\
\text { SCRATCH terlalu banyak dan kompleks } \\
\text { sehingga sulit dipahami }\end{array}$ \\
\hline I. 3-1 & P.3.1 & $\begin{array}{lcc}\text { Dengan } & \text { menggunakan SCRATCH saya } \\
\text { menjadi } & \text { lebih produktif dalam }\end{array}$ \\
\hline
\end{tabular}




\begin{tabular}{|c|c|c|}
\hline $\begin{array}{c}\text { Indika } \\
\text { tor }\end{array}$ & $\begin{array}{c}\text { Kode } \\
\text { Pernya } \\
\text { taan }\end{array}$ & Pernyataan \\
\hline & & $\begin{array}{l}\text { menghasilkan media pembelajaran yang } \\
\text { diperlukan }\end{array}$ \\
\hline \multirow[t]{3}{*}{ I. $3-2$} & P.3.2 & $\begin{array}{l}\text { Dengan menggunakan SCRATCH } \\
\text { membantu saya meningkatkan kualitas } \\
\text { pekerjaan saya }\end{array}$ \\
\hline & P.3.3 & $\begin{array}{l}\text { Dengan menggunakan SCRATCH saya } \\
\text { dapat membuat media pembelajaran yang } \\
\text { lebih menarik }\end{array}$ \\
\hline & P.3.4 & $\begin{array}{l}\text { Dengan menggunakan SCRATCH saya } \\
\text { dapat membuat media pembelajaran yang } \\
\text { lebih berkualitas }\end{array}$ \\
\hline I. $3-3$ & P.3.5 & $\begin{array}{l}\text { SCRATCH memiliki fitur-fitur yang } \\
\text { lengkap untuk mendukung proses } \\
\text { pembuatan media pembelajaran }\end{array}$ \\
\hline \multirow[t]{4}{*}{ I.4-1 } & P.4.1 & $\begin{array}{l}\text { Mudah bagi saya untuk memahami menu- } \\
\text { menu yang ada pada SCRATCH }\end{array}$ \\
\hline & P.4.2 & $\begin{array}{l}\text { Mudah bagi saya untuk mempelajari fitur- } \\
\text { fitur yang ada pada SCRATCH }\end{array}$ \\
\hline & P.4.3 & $\begin{array}{l}\text { Mudah bagi mencari referensi yang } \\
\text { diperlukan sehubungan dengan penggunaan } \\
\text { SCRATCH }\end{array}$ \\
\hline & P.4.4 & $\begin{array}{l}\text { Menurut saya SCRATCH menyediakan } \\
\text { panduan atau fasilitas bantuan (help) yang } \\
\text { langkap }\end{array}$ \\
\hline I.4-2 & P.4.5 & $\begin{array}{l}\text { Menurut saya SCRATCH memiliki fitur- } \\
\text { fitur yang mudah digunakan }\end{array}$ \\
\hline I.4-3 & P.4.6 & $\begin{array}{l}\text { SCRATCH dapat digunakan pada berbagai } \\
\text { perangkat yang berbeda platform }\end{array}$ \\
\hline I. $4-4$ & P.4.7 & $\begin{array}{l}\text { Proses instalasi SCRATCH mudah } \\
\text { dilakukan }\end{array}$ \\
\hline I. $4-5$ & P. 4.8 & $\begin{array}{l}\text { Menurut saya SCRATCH memiliki } \\
\text { antarmuka yang } \text { user-friendly }\end{array}$ \\
\hline I.5-1 & P.5.1 & $\begin{array}{l}\text { Saya ingin selalu menggunakan SCRATCH } \\
\text { setiap membuat media pembelajaran }\end{array}$ \\
\hline I. $5-2$ & P.5.2 & $\begin{array}{l}\text { Saya berencana untuk tetap menggunakan } \\
\text { SCRATCH di masa yang akan datang }\end{array}$ \\
\hline \multirow[t]{3}{*}{ I.5-3 } & P.5.3 & $\begin{array}{l}\text { Saya memperkenalkan SCRATCH kepada } \\
\text { orang lain atau rekan kerja saya }\end{array}$ \\
\hline & P.5.4 & $\begin{array}{l}\text { Saya menyarankan orang lain atau rekan } \\
\text { kerja saya agar menggunakan SCRATCH }\end{array}$ \\
\hline & P.5.5 & $\begin{array}{l}\text { Saya mengajarkan SCRATCH kepada } \\
\text { orang lain atau rekan kerja saya }\end{array}$ \\
\hline I.6-1 & P.6.1 & $\begin{array}{l}\text { Saya menggunakan SCRATCH } \\
\text { sehubungan dengan profesi pekerjaan saya }\end{array}$ \\
\hline \multirow[t]{2}{*}{ I.6-2 } & P.6.2 & $\begin{array}{l}\text { Saya merasa puas menggunakan } \\
\text { SCRATCH dalam mendukung pekerjaan } \\
\text { saya }\end{array}$ \\
\hline & P.6.3 & $\begin{array}{l}\text { Saya lebih menyukai SCRATCH } \\
\text { dibandingkan aplikasi sejenis lainnya yang } \\
\text { biasa saya gunakan }\end{array}$ \\
\hline I.6-3 & P.6.4 & $\begin{array}{l}\text { Saya merasakan hasil media pembelajaran } \\
\text { yang dihasilkan oleh SCRATCH lebih } \\
\text { bermanfaat }\end{array}$ \\
\hline
\end{tabular}

Sumber : (Goldie Gunadi \& Sudaryana, 2020)

\section{Uji Validitas}

Uji validitas pada tingkat signifikansi 0,05 dengan 2 sisi untuk jumlah responden $(\mathrm{N})$ sebanyak 8 menggunakan nilai $r$ tabel : 0,707.

1. Hasil uji validitas terhadap jawaban pernyataan indikator Efikasi Diri:

\begin{tabular}{|c|c|c|c|c|c|c|}
\hline \multicolumn{7}{|c|}{ Correlations } \\
\hline & & P.1.1 & P.1.2 & P.1.3 & P.1.4 & Total.P.1 \\
\hline \multirow[t]{3}{*}{ P.1.1 } & Pearson Correlation & 1 & .453 & .408 & .590 & $.777^{\circ}$ \\
\hline & Sig. (2-tailed) & & .260 & .315 & 124 & .023 \\
\hline & $\mathrm{N}$ & 8 & 8 & 8 & 8 & 8 \\
\hline \multirow[t]{3}{*}{ P.1.2 } & Pearson Correlation & .453 & 1 & .647 & .568 & $.841^{\prime \prime}$ \\
\hline & Sig. (2-tailed) & .260 & & .083 & .142 & .009 \\
\hline & $\mathrm{N}$ & 8 & 8 & 8 & 8 & 8 \\
\hline \multirow[t]{3}{*}{ P.1.3 } & Pearson Correlation & .408 & .647 & 1 & .602 & $.776^{\circ}$ \\
\hline & Sig. (2-tailed) & .315 & .083 & & .114 & .024 \\
\hline & $\mathrm{N}$ & 8 & 8 & 8 & 8 & 8 \\
\hline \multirow[t]{3}{*}{ P.1.4 } & Pearson Correlation & .590 & .568 & .602 & 1 & $.841^{\prime \prime}$ \\
\hline & Sig. (2-tailed) & .124 & .142 & .114 & & .009 \\
\hline & $\mathrm{N}$ & 8 & 8 & 8 & 8 & 8 \\
\hline \multirow[t]{3}{*}{ Total.P.1 } & Pearson Correlation & $.777^{\circ}$ & $.841^{\prime \prime}$ & $.776^{*}$ & $.841^{\mathrm{k}}$ & 1 \\
\hline & Sig. (2-tailed) & .023 & .009 & .024 & .009 & \\
\hline & $\mathrm{N}$ & 8 & 8 & 8 & 8 & 8 \\
\hline
\end{tabular}

Sumber : (Goldie Gunadi \& Sudaryana, 2020) Gambar 3. Hasil Uji Validitas Indikator Efikasi Diri

Hasil nilai $r$ hitung dan signifikansi untuk indikator Efikasi Diri:

Tabel 8. Nilai R Hitung dan Signifikansi Indikator

\begin{tabular}{cccc}
\multicolumn{4}{c}{ Efikasi Diri } \\
\hline $\begin{array}{c}\text { Kode } \\
\text { Pernyataan }\end{array}$ & $\begin{array}{c}\text { Pearson } \\
\text { Correlation } \\
\text { (r hitung) }\end{array}$ & $\begin{array}{c}\text { Nilai } \\
\text { Signifikansi }\end{array}$ & Kesimpulan \\
\hline P.1.1 & 0,777 & 0,023 & Valid \\
P.1.2 & 0,841 & 0,009 & Valid \\
P.1.3 & 0,776 & 0,024 & Valid \\
P.1.4 & 0,841 & 0,009 & Valid \\
\hline
\end{tabular}

Sumber : (Goldie Gunadi \& Sudaryana, 2020)

Kesimpulannya, semua pernyataan pada indikator Efikasi Diri dinyatakan valid.

2. Hasil uji validitas terhadap jawaban pernyataan indikator Kerumitan:

\begin{tabular}{|c|c|c|c|c|c|}
\hline \multicolumn{6}{|c|}{ Correlations } \\
\hline & & P.2.1 & P. 2.2 & P. 2.3 & Total.P.2 \\
\hline \multirow[t]{3}{*}{ P.2.1 } & Pearson Correlation & 1 & $.709^{\kappa}$ & .440 & $.782^{\prime \prime}$ \\
\hline & Sig. (2-tailed) & & .049 & .275 & .022 \\
\hline & $\mathrm{N}$ & 8 & 8 & 8 & 8 \\
\hline \multirow[t]{3}{*}{ P. 2.2} & Pearson Correlation & $.709^{*}$ & 1 & $.798^{*}$ & $.954^{k \prime}$ \\
\hline & Sig. (2-tailed) & .049 & & .018 & .000 \\
\hline & $\mathrm{N}$ & 8 & 8 & 8 & 8 \\
\hline \multirow[t]{3}{*}{ P. 2.3} & Pearson Correlation & .440 & $.798^{*}$ & 1 & $.884^{\prime \prime}$ \\
\hline & Sig. (2-tailed) & .275 & .018 & & .004 \\
\hline & $\mathrm{N}$ & 8 & 8 & 8 & 8 \\
\hline \multirow[t]{3}{*}{ Total.P. 2} & Pearson Correlation & $.782^{*}$ & $.954^{* *}$ & $.884^{\mathrm{N}}$ & 1 \\
\hline & Sig. (2-tailed) & .022 & .000 & .004 & \\
\hline & $\mathrm{N}$ & 8 & 8 & 8 & 8 \\
\hline
\end{tabular}

Sumber :(Goldie Gunadi \& Sudaryana, 2020)

Gambar 4. Hasil Uji Validitas Indikator Kerumitan

Hasil nilai $r$ hitung dan signifikansi untuk indikator Kerumitan: 
Tabel 9. Nilai R Hitung dan Signifikansi Indikator Kerumitan

\begin{tabular}{cccc}
\hline $\begin{array}{c}\text { Kode } \\
\text { Pernyataan }\end{array}$ & $\begin{array}{c}\text { Pearson } \\
\text { Correlation } \\
\text { (r hitung) }\end{array}$ & $\begin{array}{c}\text { Nilai } \\
\text { Signifikansi }\end{array}$ & Kesimpulan \\
\hline P.2.1 & 0,782 & 0,022 & Valid \\
P.2.2 & 0,954 & 0,000 & Valid \\
P.2.3 & 0,884 & 0,004 & Valid \\
\hline
\end{tabular}

Sumber : (Goldie Gunadi \& Sudaryana, 2020)

Kesimpulannya, semua pernyataan pada indikator Kerumitan dinyatakan valid.

3. Hasil uji validitas terhadap jawaban pernyataan indikator Persepsi Kegunaan:

\begin{tabular}{|c|c|c|c|c|c|c|c|}
\hline \multicolumn{8}{|c|}{ Correlations } \\
\hline & & P.3.1 & P. 3.2 & P.3.3 & P.3.4 & P. 3.5 & Total.P. 3 \\
\hline \multirow[t]{3}{*}{ P.3.1 } & Pearson Correlation & 1 & $.834^{\circ}$ & $.834^{\circ}$ & $.834^{\circ}$ & .516 & $.905^{\prime \prime}$ \\
\hline & Sig. (2-tailed) & & .010 & .010 & .010 & .190 & .002 \\
\hline & $\mathrm{N}$ & 8 & 8 & 8 & 8 & 8 & 8 \\
\hline \multirow[t]{3}{*}{ P. 3.2} & Pearson Correlation & $.834^{*}$ & 1 & $1.000^{\prime \prime}$ & .652 & .700 & $.943^{\mathrm{m}}$ \\
\hline & Sig. (2-tailed) & .010 & & .000 & .080 & .053 & .000 \\
\hline & $\mathrm{N}$ & 8 & 8 & 8 & 8 & 8 & 8 \\
\hline \multirow[t]{3}{*}{ P.3.3 } & Pearson Correlation & $.834^{\circ}$ & $1.000^{\prime \prime}$ & 1 & .652 & .700 & $.943^{\prime \prime}$ \\
\hline & Sig. (2-tailed) & .010 & .000 & & .080 & .053 & .000 \\
\hline & $\mathrm{N}$ & 8 & 8 & 8 & 8 & 8 & 8 \\
\hline \multirow[t]{3}{*}{ P.3.4 } & Pearson Correlation & $.834^{*}$ & .652 & .652 & 1 & .700 & $.859^{\prime \prime}$ \\
\hline & Sig. (2-tailed) & .010 & .080 & .080 & & .053 & .006 \\
\hline & $\mathrm{N}$ & 8 & 8 & 8 & 8 & 8 & 8 \\
\hline \multirow[t]{3}{*}{ P. 3.5} & Pearson Correlation & .516 & .700 & .700 & .700 & 1 & $.804^{\circ}$ \\
\hline & Sig. (2-tailed) & .190 & .053 & .053 & .053 & & .016 \\
\hline & $\mathrm{N}$ & 8 & 8 & 8 & 8 & 8 & 8 \\
\hline \multirow[t]{3}{*}{ Total.P. 3} & Pearson Correlation & $.905^{\mathrm{k \prime}}$ & $.943^{\mathrm{m}}$ & $.943^{\prime \prime}$ & $.859^{\prime \prime}$ & $.804^{*}$ & 1 \\
\hline & Sig. (2-tailed) & .002 & .000 & .000 & .006 & .016 & \\
\hline & $\mathrm{N}$ & 8 & 8 & 8 & 8 & 8 & 8 \\
\hline
\end{tabular}

Sumber : (Goldie Gunadi \& Sudaryana, 2020)

Gambar 5. Hasil Uji Validitas Indikator Persepsi

$$
\text { Kegunaan }
$$

Hasil nilai $\mathrm{r}$ hitung dan signifikansi untuk indikator Persepsi Kegunaan:

Tabel 10. Nilai R Hitung dan Signifikansi Indikator Persepsi Kegunaan

\begin{tabular}{cccc}
\hline $\begin{array}{c}\text { Kode } \\
\text { Pernyataan }\end{array}$ & $\begin{array}{c}\text { Pearson } \\
\text { Correlation } \\
\text { (r hitung) }\end{array}$ & $\begin{array}{c}\text { Nilai } \\
\text { Signifikansi }\end{array}$ & Kesimpulan \\
\hline P.3.1 & 0,905 & 0,002 & Valid \\
P.3.2 & 0,943 & 0,000 & Valid \\
P.3.3 & 0,943 & 0,000 & Valid \\
P.3.4 & 0,859 & 0,006 & Valid \\
P.3.5 & 0,804 & 0,016 & Valid \\
\hline
\end{tabular}

Sumber : (Goldie Gunadi \& Sudaryana, 2020)

Kesimpulannya, semua pernyataan pada indikator Persepsi Kegunaan dinyatakan valid.

4. Hasil uji validitas terhadap jawaban pernyataan indikator Persepsi Kemudahan Penggunaan:

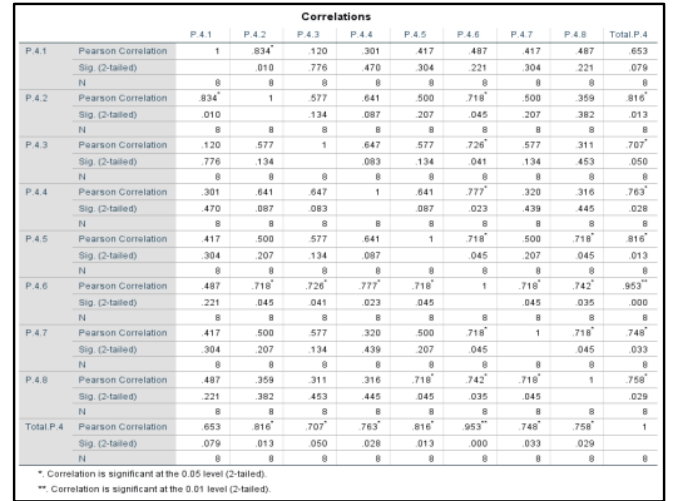

Sumber : (Goldie Gunadi \& Sudaryana, 2020) Gambar 6. Hasil Uji Validitas Indikator Persepsi Kemudahan Penggunaan

Hasil nilai $r$ hitung dan signifikansi untuk indikator Persepsi Kemudahan Penggunaan:

Tabel 11. Nilai R Hitung dan Signifikansi Indikator Persepsi Kemudahan Penggunaan

\begin{tabular}{cccc}
\hline $\begin{array}{c}\text { Kode } \\
\text { Pernyataan }\end{array}$ & $\begin{array}{c}\text { Pearson } \\
\text { Correlation } \\
\text { (r hitung) }\end{array}$ & $\begin{array}{c}\text { Nilai } \\
\text { Signifikansi }\end{array}$ & Kesimpulan \\
\hline P.4.1 & 0,762 & 0,079 & Tidak Valid \\
P.4.2 & 0,816 & 0,013 & Valid \\
P.4.3 & 0,707 & 0,050 & Valid \\
P.4.4 & 0,763 & 0,028 & Valid \\
P.4.5 & 0,816 & 0,013 & Valid \\
P.4.6 & 0,953 & 0,000 & Valid \\
P.4.7 & 0,748 & 0,033 & Valid \\
P.4.8 & 0,758 & 0,029 & Valid \\
\hline
\end{tabular}

Sumber : (Goldie Gunadi \& Sudaryana, 2020)

Data pernyataan P.4.1 (Mudah bagi saya untuk memahami menu-menu yang ada pada Scratch) pada indikator Kemudahan Penggunaan dinyatakan tidak valid sehingga tidak akan diproses lebih lanjut.

5. Hasil uji validitas terhadap jawaban pernyataan indikator Intensi Penggunaan:

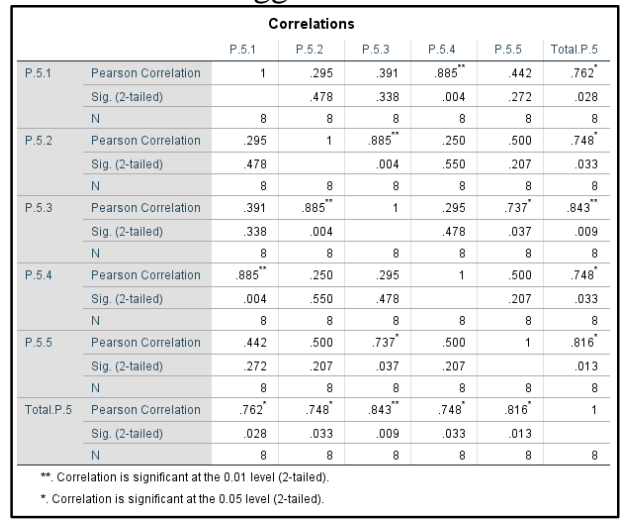

Sumber : (Goldie Gunadi \& Sudaryana, 2020)

Gambar 7. Hasil Uji Validitas Indikator Intensi Penggunaan 
Hasil nilai $\mathrm{r}$ hitung dan signifikansi untuk indikator Intensi Penggunaan:

Tabel 12. Nilai R Hitung dan Signifikansi Indikator Intensi Penggunaan

\begin{tabular}{cccc}
\hline $\begin{array}{c}\text { Kode } \\
\text { Pernyataan }\end{array}$ & $\begin{array}{c}\text { Pearson } \\
\text { Correlation } \\
\text { (r hitung) }\end{array}$ & $\begin{array}{c}\text { Nilai } \\
\text { Signifikansi }\end{array}$ & Kesimpulan \\
\hline P.5.1 & 0,762 & 0,028 & Valid \\
P.5.2 & 0,748 & 0,033 & Valid \\
P.5.3 & 0,843 & 0,009 & Valid \\
P.5.4 & 0,748 & 0,033 & Valid \\
P.5.5 & 0,816 & 0,013 & Valid \\
\hline
\end{tabular}

Sumber : (Goldie Gunadi \& Sudaryana, 2020)

Kesimpulannya, semua pernyataan pada indikator Intensi Penggunaan dinyatakan valid.

6. Hasil analisa korelasi bivariate terhadap jawaban pernyataan indikator Penggunaan Teknologi Sesungguhnya:

\begin{tabular}{|c|c|c|c|c|c|c|}
\hline \multicolumn{7}{|c|}{ Correlations } \\
\hline & & P.6.1 & P.6.2 & P.6.3 & P.6.4 & Total.P. 6 \\
\hline \multirow[t]{3}{*}{ P.6.1 } & Pearson Correlation & 1 & .590 & .394 & $.739^{x}$ & $.795^{*}$ \\
\hline & Sig. (2-tailed) & & .124 & .334 & .036 & .018 \\
\hline & $\mathrm{N}$ & 8 & 8 & 8 & 8 & 8 \\
\hline \multirow[t]{3}{*}{ P.6.2 } & Pearson Correlation & .590 & 1 & .535 & .590 & $.816^{*}$ \\
\hline & Sig. (2-tailed) & .124 & & .172 & .124 & .013 \\
\hline & $\mathrm{N}$ & 8 & 8 & 8 & 8 & 8 \\
\hline \multirow[t]{3}{*}{ P.6.3 } & Pearson Correlation & .394 & .535 & 1 & $.867^{* *}$ & $.829^{\circ}$ \\
\hline & Sig. (2-tailed) & .334 & .172 & & .005 & .011 \\
\hline & $\mathrm{N}$ & 8 & 8 & 8 & 8 & 8 \\
\hline \multirow[t]{3}{*}{ P.6.4 } & Pearson Correlation & $.739^{*}$ & .590 & $.867^{\prime \prime \prime}$ & 1 & $.939^{\mathrm{kN}}$ \\
\hline & Sig. (2-tailed) & .036 & .124 & .005 & & .001 \\
\hline & $\mathrm{N}$ & 8 & 8 & 8 & 8 & 8 \\
\hline \multirow[t]{3}{*}{ Total.P. 6} & Pearson Correlation & $.795^{*}$ & $.816^{*}$ & $.829^{\circ}$ & $.939^{\mathrm{k}}$ & 1 \\
\hline & Sig. (2-tailed) & .018 & .013 & .011 & .001 & \\
\hline & $\mathrm{N}$ & 8 & 8 & 8 & 8 & 8 \\
\hline
\end{tabular}

Sumber : (Goldie Gunadi \& Sudaryana, 2020)

Gambar 8. Hasil Uji Validitas Indikator Penggunaan Teknologi Sesungguhnya

Hasil nilai $r$ hitung dan signifikansi untuk indikator Penggunaan Teknologi Sesungguhnya:

Tabel 13. Nilai R Hitung dan Signifikansi Indikator Penggunaan Teknologi Sesungguhnya

\begin{tabular}{cccc}
\hline $\begin{array}{c}\text { Kode } \\
\text { Pernyataan }\end{array}$ & $\begin{array}{c}\text { Pearson } \\
\text { Correlation } \\
\text { (r hitung) }\end{array}$ & $\begin{array}{c}\text { Nilai } \\
\text { Signifikansi }\end{array}$ & Kesimpula \\
\hline P.6.1 & 0,795 & 0,018 & Valid \\
P.6.2 & 0,816 & 0,013 & Valid \\
P.6.3 & 0,829 & 0,011 & Valid \\
P.6.4 & 0,939 & 0,001 & Valid \\
\hline
\end{tabular}

Sumber : (Goldie Gunadi \& Sudaryana, 2020)

Kesimpulannya, semua pernyataan pada indikator Penggunaan Teknologi Sesungguhnya dinyatakan valid.

\section{Uji Reliabilitas}

Berikut adalah hasil uji reliabilitas dari setiap indikator:

Tabel 14. Hasil Uji Reliabilitas

\begin{tabular}{|c|c|c|c|}
\hline Indikator & $\begin{array}{c}\text { Jumlah } \\
\text { Item }\end{array}$ & $\begin{array}{l}\text { Cronbach } \\
\text { 's Alpha }\end{array}$ & Kesimpulan \\
\hline Efikasi Diri & 4 & 0,806 & $\begin{array}{c}\text { Reliable } \\
\text { (Baik) }\end{array}$ \\
\hline Kerumitan & 3 & 0,837 & $\begin{array}{c}\text { Reliable } \\
\text { (Baik) }\end{array}$ \\
\hline $\begin{array}{l}\text { Persepsi } \\
\text { Kegunaan }\end{array}$ & 5 & 0,934 & $\begin{array}{l}\text { Reliable } \\
\text { (Baik) }\end{array}$ \\
\hline $\begin{array}{l}\text { Persepsi } \\
\text { Kemudahan } \\
\text { Penggunaan }\end{array}$ & 7 & 0,899 & $\begin{array}{c}\text { Reliable } \\
\text { (Baik) }\end{array}$ \\
\hline $\begin{array}{l}\text { Intensi } \\
\text { Penggunaan }\end{array}$ & 5 & 0,839 & $\begin{array}{c}\text { Reliable } \\
\text { (Baik) }\end{array}$ \\
\hline $\begin{array}{l}\text { Penggunaan } \\
\text { Teknologi } \\
\text { Sesungguhnya }\end{array}$ & 4 & 0,862 & $\begin{array}{c}\text { Reliable } \\
\text { (Baik) }\end{array}$ \\
\hline
\end{tabular}

Sumber : (Goldie Gunadi \& Sudaryana, 2020)

Dari hasil pengujian, semua indikator dinyatakan dapat diterima (reliable) dengan nilai Cronbach's Alpha lebih besar dari 0,8 sehingga dinyatakan baik.

\section{Analisis Regresi Linier}

Berikut ini adalah sejumlah hipotesa yang digunakan dalam analisis regresi linier.

Tabel 15. Tabel Hipotesa Pengujian

\begin{tabular}{|c|c|c|}
\hline $\begin{array}{c}\text { Variabel } \\
\text { Dependen (Y) }\end{array}$ & $\begin{array}{l}\text { Variabel Independen } \\
(\mathrm{X})\end{array}$ & Hipotesa \\
\hline $\begin{array}{l}\text { Penggunaan } \\
\text { Teknologi } \\
\text { Sesungguhnya }\end{array}$ & Intensi Penggunaan & $\mathrm{H} 1$ \\
\hline Intensi Penggunaan & $\begin{array}{l}\text { Persepsi Kegunaan, } \\
\text { Persepsi Kemudahan } \\
\text { Penggunaan } \\
\text { Persepsi Kegunaan } \\
\text { Persepsi Kemudahan } \\
\text { Penggunaan }\end{array}$ & $\begin{array}{l}\mathrm{H} 3 \\
\mathrm{H} 4\end{array}$ \\
\hline Persepsi Kegunaan & $\begin{array}{c}\text { Persepsi Kemudahan } \\
\text { Penggunaan, Efikasi } \\
\text { Diri, Kerumitan } \\
\text { Persepsi Kemudahan } \\
\text { Penggunaan } \\
\text { Efikasi Diri } \\
\text { Kerumitan } \\
\end{array}$ & $\begin{array}{l}\text { H6 } \\
\text { H7 } \\
\text { H8 }\end{array}$ \\
\hline $\begin{array}{c}\text { Persepsi } \\
\text { Kemudahan } \\
\text { Penggunaan }\end{array}$ & $\begin{array}{c}\text { Efikasi Diri, } \\
\text { Kerumitan } \\
\text { Efikasi Diri } \\
\text { Kerumitan }\end{array}$ & $\begin{array}{l}\text { H9 } \\
\text { H10 } \\
\text { H11 }\end{array}$ \\
\hline
\end{tabular}

Sumber : (Goldie Gunadi \& Sudaryana, 2020)

1. Berikut hasil analisa Regresi Linear untuk mengukur pengaruh variabel independen Intensi $(\mathrm{X})$ terhadap variabel dependen Penggunaan Teknologi Sesungguhnya $(\mathrm{Y})$ : 


\begin{tabular}{|c|c|c|c|c|c|c|}
\hline \multicolumn{7}{|c|}{ ANOVA $^{a}$} \\
\hline \multicolumn{2}{|c|}{ Model } & $\begin{array}{l}\text { Sum of } \\
\text { Squares }\end{array}$ & df & Mean Square & $\mathrm{F}$ & Sig. \\
\hline \multirow[t]{3}{*}{1} & Regression & 25.352 & 1 & 25.352 & 12.521 & $.012^{\mathrm{b}}$ \\
\hline & Residual & 12.148 & 6 & 2.025 & & \\
\hline & Total & 37.500 & 7 & & & \\
\hline \multicolumn{7}{|c|}{ a. Dependent Variable: Penggunaan Teknologi Sesungguhnya } \\
\hline \multicolumn{7}{|c|}{ b. Predictors: (Constant), Intensi Penggunaan } \\
\hline
\end{tabular}

Sumber : (Goldie Gunadi \& Sudaryana, 2020)

Gambar 9. Tabel ANOVA Variabel Dependen

Penggunaan Teknologi Sesungguhnya

\begin{tabular}{|c|c|c|c|c|c|c|}
\hline \multicolumn{7}{|c|}{ Coefficients $^{\mathrm{a}}$} \\
\hline \multirow[b]{2}{*}{ Model } & & \multicolumn{2}{|c|}{ Unstandardized Coefficients } & \multirow{2}{*}{$\begin{array}{l}\text { Standardized } \\
\text { Coefficients } \\
\text { Beta }\end{array}$} & \multirow[b]{2}{*}{$\mathrm{t}$} & \multirow[b]{2}{*}{ Sig. } \\
\hline & & B & Std. Error & & & \\
\hline 1 & (Constant) & 2.389 & 3.809 & & .627 & .554 \\
\hline & Intensi Penggunaan & .685 & .194 & .822 & 3.539 & .012 \\
\hline
\end{tabular}

Sumber : (Goldie Gunadi \& Sudaryana, 2020)

Gambar 10. Tabel Koefisien Variabel Independen

Terhadap Penggunaan Teknologi Sesungguhnya

Persamaan regresi linier :

$$
Y=(2,389)+(0,685) X
$$

Uji t

Pengujian hipotesa $\mathrm{H} 1$

Tabel 16. Tabel Hipotesa H1

\begin{tabular}{clrr}
\hline Kode & \multicolumn{3}{c}{ Hipotesa } \\
\hline Ho & Intensi & Penggunaan tidak & berpengaruh \\
& terhadap & Penggunaan & Teknologi \\
& Sesungguhnya &
\end{tabular}

Ha Intensi Penggunaan berpengaruh terhadap Penggunaan Teknologi Sesungguhnya

Sumber : (Goldie Gunadi \& Sudaryana, 2020)

Nilai t hitung : 3,539

$\mathrm{df}=6$, maka t tabel $($ Uji 2 sisi $)=2,447$

t hitung $(3,539)>t$ tabel $(2,447)$ maka Ho ditolak.

Jadi dapat disimpulkan bahwa Intensi Penggunaan berpengaruh terhadap Penggunaan Teknologi Sesungguhnya.

2. Berikut hasil analisa Regresi Linear untuk mengukur pengaruh variabel independen Persepsi Kegunaan $\left(\mathrm{X}_{1}\right)$ dan Persepsi Kemudahan Penggunaan $\left(\mathrm{X}_{2}\right)$ terhadap variabel dependen Intensi Penggunaan $(\mathrm{Y})$ :

\begin{tabular}{|c|c|c|c|c|c|c|}
\hline \multicolumn{7}{|c|}{ ANOVA $^{a}$} \\
\hline \multicolumn{2}{|c|}{ Model } & $\begin{array}{l}\text { Sum of } \\
\text { Squares }\end{array}$ & df & Mean Square & $\mathrm{F}$ & Sig. \\
\hline \multirow[t]{3}{*}{1} & Regression & 48.987 & 2 & 24.494 & 24.430 & $.003^{\mathrm{b}}$ \\
\hline & Residual & 5.013 & 5 & 1.003 & & \\
\hline & Total & 54.000 & 7 & & & \\
\hline \multicolumn{7}{|c|}{ a. Dependent Variable: Intensi Penggunaan } \\
\hline \multicolumn{7}{|c|}{ b. Predictors: (Constant), Persepsi Kemudahan Penggunaan, Persepsi Kegunaan } \\
\hline
\end{tabular}

Sumber : (Goldie Gunadi \& Sudaryana, 2020)

Gambar 11. Tabel ANOVA Variabel Dependen Intensi Penggunaan

\begin{tabular}{|c|c|c|c|c|c|c|}
\hline \multicolumn{7}{|c|}{ Coefficients ${ }^{a}$} \\
\hline \multirow[b]{2}{*}{ Model } & & \multicolumn{2}{|c|}{ Unstandardized Coefficients } & \multirow{2}{*}{$\begin{array}{c}\text { Standardized } \\
\text { Coefficients } \\
\text { Beta }\end{array}$} & \multirow[b]{2}{*}{$\mathrm{t}$} & \multirow[b]{2}{*}{ Sig. } \\
\hline & & B & Std. Error & & & \\
\hline \multirow[t]{3}{*}{1} & (Constant) & -2.370 & 3.178 & & -.746 & .489 \\
\hline & Persepsi Kegunaan & .720 & .214 & .690 & 3.366 & .020 \\
\hline & $\begin{array}{l}\text { Persepsi Kemudahan } \\
\text { Penggunaan }\end{array}$ & .251 & .161 & .320 & 1.561 & .179 \\
\hline
\end{tabular}

Gambar 12. Tabel Koefisien Variabel Independen

Terhadap Intensi Penggunaan

Sumber : (Goldie Gunadi \& Sudaryana, 2020)

Persamaan regresi linier berganda :

$$
Y=(-2,370)+(0,720) X_{1}+(0,251) X_{2}
$$

Uji F

Pengujian hipotesa $\mathrm{H} 2$

Tabel 17. Tabel Hipotesa H2

\begin{tabular}{cl}
\hline Kode & \multicolumn{1}{c}{ Hipotesa } \\
\hline Ho & $\begin{array}{l}\text { Persepsi Kegunaan dan Persepsi Kemudahan } \\
\text { Penggunaan secara bersama-sama tidak }\end{array}$ \\
& berpengaruh terhadap Intensi Penggunaan \\
Ha & $\begin{array}{l}\text { Persepsi Kegunaan dan Persepsi Kemudahan } \\
\text { Penggunaan secara bersama-sama } \\
\text { berpengaruh terhadap Intensi Penggunaan }\end{array}$ \\
\hline
\end{tabular}

Sumber : (Goldie Gunadi \& Sudaryana, 2020)

Nilai F hitung : 24,430

$\mathrm{F}$ tabel $=\mathrm{F}(2,6)=5,14$

F hitung $(24,430)>F$ tabel $(5,14)$ maka Ho ditolak.

Nilai signifikansi penggaruh Persepsi Kegunaan dan

Persepsi Kemudahan Penggunaan secara bersamasama terhadap Intensi Penggunaan sebesar 0,003 ( $\leq$ $0,05)$ yang artinya Ho ditolak.

Jadi dapat disimpulkan bahwa Persepsi Kegunaan dan Persepsi Kemudahan Penggunaan secara bersama-sama berpengaruh terhadap Intensi

Penggunaan.

Uji t

Pengujian hipotesa $\mathrm{H} 3$

\begin{tabular}{|c|c|}
\hline Kode & Hipotesa \\
\hline Ho & $\begin{array}{l}\text { Persepsi Kegunaan secara parsial tidak } \\
\text { berpengaruh terhadap Intensi Penggunaan }\end{array}$ \\
\hline $\mathrm{Ha}$ & $\begin{array}{l}\text { Persepsi Kegunaan secara parsial } \\
\text { berpengaruh terhadap Intensi Penggunaan }\end{array}$ \\
\hline \multicolumn{2}{|r|}{ Sumber : (Goldie Gunadi \& Sudaryana, 2020) } \\
\hline $\begin{array}{l}\text { Nila } \\
\text { t tab } \\
\text { t hit } \\
\text { Nila } \\
\text { seca } \\
0,02\end{array}$ & $\begin{array}{l}\text { hitung : } 3,366 \\
=\mathrm{t}(0,025,5)=2,571 \\
\mathrm{~g}(3,366)>\mathrm{t} \text { tabel }(2,571) \text { maka Ho ditolak. } \\
\text { signifikansi penggaruh Persepsi Kegunaan } \\
\text { parsial terhadap Intensi Penggunaan sebesar } \\
(\leq 0,05) \text { yang artinya Ho ditolak. }\end{array}$ \\
\hline
\end{tabular}

Tabel 18. Tabel Hipotesa H3 
Jadi dapat disimpulkan bahwa Persepsi Kegunaan secara parsial berpengaruh terhadap Intensi Penggunaan.

Pengujian hipotesa H4

Tabel 19. Tabel Hipotesa H4

\begin{tabular}{clll}
\hline Kode & \multicolumn{3}{c}{ Hipotesa } \\
\hline Ho & $\begin{array}{l}\text { Persepsi Kemudahan Penggunaan } \\
\text { parsial tidak berpengaruh terhadap }\end{array}$ & Intensi \\
& $\begin{array}{l}\text { Penggunaan } \\
\text { Ha }\end{array}$ & $\begin{array}{l}\text { Persepsi Kemudahan } \\
\text { parsial benggunaan }\end{array}$ & secara \\
& Penggunaan & & \\
\hline
\end{tabular}

Sumber : (Goldie Gunadi \& Sudaryana, 2020)

Nilai thitung : 1,561

$\mathrm{t}$ tabel $=\mathrm{t}(0,025,5)=2,571$

$t$ hitung $(1,561) \leq t$ tabel $(2,571)$ maka Ho diterima.

Nilai signifikansi penggaruh Persepsi Kemudahan

Penggunaan secara parsial terhadap Intensi

Penggunaan sebesar 0,179 $(>0,05)$ yang artinya Ho diterima.

Jadi dapat disimpulkan bahwa Persepsi Kemudahan Penggunaan secara parsial tidak berpengaruh terhadap Intensi Penggunaan.

3. Berikut hasil analisa Regresi Linear untuk mengukur pengaruh variabel independen Persepsi Kemudahan Penggunaan $\left(\mathrm{X}_{1}\right)$, Efikasi Diri $\left(\mathrm{X}_{2}\right)$ dan Kerumitan $\left(\mathrm{X}_{3}\right)$ terhadap variabel dependen Persepsi Kegunaan:

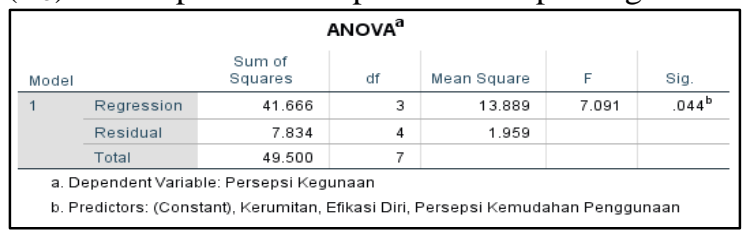

Sumber : (Goldie Gunadi \& Sudaryana, 2020)

Gambar 13. Tabel ANOVA Variabel Dependen Persepsi Kegunaan

\begin{tabular}{|c|c|c|c|c|c|c|}
\hline \multicolumn{7}{|c|}{ Coefficients $^{\mathrm{a}}$} \\
\hline \multirow[b]{2}{*}{ Model } & & \multicolumn{2}{|c|}{ Unstandardized Coefficients } & \multirow{2}{*}{$\begin{array}{c}\text { Standardized } \\
\text { Coefficients } \\
\text { Beta }\end{array}$} & \multirow[b]{2}{*}{$t$} & \multirow[b]{2}{*}{ Sig. } \\
\hline & & B & Std. Error & & & \\
\hline \multirow[t]{4}{*}{1} & (Constant) & .921 & 4.518 & & .204 & .848 \\
\hline & $\begin{array}{l}\text { Persepsi Kemudahan } \\
\text { Penggunaan }\end{array}$ & .308 & .215 & .410 & 1.435 & .225 \\
\hline & Efikasi Diri & .857 & .320 & .705 & 2.677 & .055 \\
\hline & Kerumitan & -.214 & .366 & -158 & .585 & .590 \\
\hline
\end{tabular}

Sumber : (Goldie Gunadi \& Sudaryana, 2020)

Gambar 14. Tabel Koefisien Variabel Independen

Terhadap Persepsi Kegunaan

Persamaan regresi linier berganda :

$$
Y=\begin{gathered}
(0,921)+(0,308) X_{1}+(0,857) X_{2}+(- \\
0,214) X_{3}
\end{gathered}
$$

Uji F

Pengujian hipotesa H5

\begin{tabular}{|c|c|}
\hline Kode & Hipotesa \\
\hline \multirow[t]{2}{*}{ Ho } & $\begin{array}{lll}\text { Persepsi } & \text { Kemudahan } & \text { Penggunaan, }\end{array}$ \\
\hline & $\begin{array}{l}\text { Kerumitan dan Efikasi Diri secara bersama- } \\
\text { sama tidak berpengaruh terhadap Persepsi } \\
\text { Kegunaan }\end{array}$ \\
\hline \multirow[t]{2}{*}{$\mathrm{Ha}$} & Persepsi Kemudahan \\
\hline & $\begin{array}{l}\text { Kerumitan dan Efikasi Diri secara bersama- } \\
\text { sama berpengaruh terhadap Persepsi } \\
\text { Kegunaan }\end{array}$ \\
\hline
\end{tabular}

Tabel 19. Tabel Hipotesa H5

Sumber : (Goldie Gunadi \& Sudaryana, 2020)

Nilai F hitung : 7,091

$\mathrm{F}$ tabel $=\mathrm{F}(3,5)=5,41$

F hitung $(7,091)>$ F tabel $(5,41)$ maka Ho ditolak.

Nilai signifikansi penggaruh Persepsi Kemudahan

Penggunaan, Efikasi Diri dan Kerumitan secara bersama-sama terhadap Persepsi Kegunaan sebesar $0,044(\leq 0,05)$ yang artinya Ho ditolak.

Jadi dapat disimpulkan bahwa Persepsi Kemudahan Penggunaan, Efikasi Diri dan Kerumitan secara bersama-sama berpengaruh terhadap Persepsi Kegunaan.

Uji t

Pengujian hipotesa H6

Tabel 20. Tabel Hipotesa H6

\begin{tabular}{clc}
\hline Kode & \multicolumn{3}{c}{ Hipotesa } \\
\hline Ho & $\begin{array}{l}\text { Persepsi Kemudahan Penggunaan secara } \\
\text { parsial tidak berpengaruh terhadap Persepsi }\end{array}$ \\
& $\begin{array}{l}\text { Kegunaan } \\
\text { Ha }\end{array}$ \\
& $\begin{array}{l}\text { Persepsi Kemudahan Penggunaan secara } \\
\text { parsial berpengaruh terhadap Persepsi } \\
\text { Kegunaan }\end{array}$ \\
\hline
\end{tabular}

Sumber : (Goldie Gunadi \& Sudaryana, 2020)

Nilai t hitung : 1,435

$\mathrm{t}$ tabel $=\mathrm{t}(0,025,4)=2,776$

t hitung $(1,435) \leq \mathrm{t}$ tabel $(2,776)$ maka Ho diterima.

Nilai signifikansi penggaruh Persepsi Kemudahan

Penggunaan secara parsial terhadap Persepsi Kegunaan sebesar 0,225 $(>0,05)$ yang artinya Ho diterima.

Jadi dapat disimpulkan bahwa Persepsi Kemudahan Penggunaan secara parsial tidak berpengaruh terhadap Persepsi Kegunaan.

Pengujian hipotesa $\mathrm{H} 7$

Tabel 21. Tabel Hipotesa H7

\begin{tabular}{cl}
\hline Kode & \multicolumn{1}{c}{ Hipotesa } \\
\hline Ho & $\begin{array}{l}\text { Efikasi Diri secara parsial tidak berpengaruh } \\
\text { terhadap Persepsi Kegunaan }\end{array}$ \\
Ha & $\begin{array}{l}\text { Efikasi Diri secara parsial berpengaruh } \\
\text { terhadap Persepsi Kegunaan }\end{array}$ \\
\hline \multicolumn{2}{c}{ Sumber : (Goldie Gunadi \& Sudaryana, 2020) }
\end{tabular}


Nilai t hitung : 2,677

$\mathrm{t}$ tabel $=\mathrm{t}(0,025,4)=2,776$

t hitung $(2,677) \leq \mathrm{t}$ tabel $(2,776)$ maka Ho diterima.

Nilai signifikansi penggaruh Efikasi Diri secara parsial terhadap Persepsi Kegunaan sebesar 0,055 (> $0,05)$ yang artinya Ho diterima.

Jadi dapat disimpulkan bahwa Efikasi Diri secara parsial tidak berpengaruh terhadap Persepsi Kegunaan.

Pengujian hipotesa $\mathrm{H} 8$

Tabel 22. Tabel Hipotesa H8

\begin{tabular}{|c|c|c|c|c|c|c|}
\hline Kode & \multicolumn{6}{|c|}{ Hipotesa } \\
\hline Ho & \multicolumn{6}{|c|}{$\begin{array}{l}\text { Kerumitan secara parsial tidak } \\
\text { terhadap Persepsi Kegunaan }\end{array}$} \\
\hline $\mathrm{Ha}$ & \multicolumn{4}{|c|}{$\begin{array}{l}\text { Kerumitan secara parsial } \\
\text { terhadap Persepsi Kegunaan }\end{array}$} & \\
\hline \multicolumn{7}{|c|}{ Sumber : (Goldie Gunadi \& Sudaryana, 2020) } \\
\hline \multicolumn{7}{|c|}{$\begin{array}{l}\text { Nilai t hitung : }-0,585 \\
\mathrm{t} \text { tabel }=\mathrm{t}(0,025,4)=2,776 \\
\mathrm{t} \text { hitung }(-0,585) \leq \mathrm{t} \text { tabel }(2,776) \text { maka Ho diterima } \\
\text { Nilai signifikansi penggaruh Kerumitan secara } \\
\text { parsial terhadap Persepsi Kegunaan sebesar } 0,590 \text { (> } \\
\text { 0,05) yang artinya Ho diterima. } \\
\text { Jadi dapat disimpulkan bahwa Kerumitan secara } \\
\text { parsial tidak berpengaruh terhadap Persepsi } \\
\text { Kegunaan. } \\
\text { Berikut hasil analisa Regresi Linear untuk mengukur } \\
\text { pengaruh variabel independen Efikasi Diri }\left(\mathrm{X}_{1}\right) \text { dan } \\
\text { Kerumitan }\left(\mathrm{X}_{2}\right) \text { terhadap variabel dependen Persepsi } \\
\text { Kemudahan Penggunaan }(\mathrm{Y}) \text { : }\end{array}$} \\
\hline \multicolumn{7}{|c|}{ ANOVA $^{\mathrm{a}}$} \\
\hline Model & & $\begin{array}{l}\text { Sum of } \\
\text { Squares }\end{array}$ & & Mean Square & & \\
\hline \multirow[t]{3}{*}{1} & ession & 45.367 & 2 & 22.683 & 2.668 & $.163^{\mathrm{b}}$ \\
\hline & idual & 42.508 & 5 & 8.502 & & \\
\hline & otal & 87.875 & 7 & & & \\
\hline \multicolumn{6}{|c|}{ a. Dependent Variab } & \\
\hline
\end{tabular}

Sumber : (Goldie Gunadi \& Sudaryana, 2020)

Gambar 15. Tabel Anova Variabel Dependen Persepsi Kemudahan Penggunaan

\begin{tabular}{|c|c|c|c|c|c|c|}
\hline \multicolumn{7}{|c|}{ Coefficients $^{a}$} \\
\hline \multirow[b]{2}{*}{ Model } & & \multicolumn{2}{|c|}{ Unstandardized Coefficients } & \multirow{2}{*}{$\begin{array}{l}\text { Standardized } \\
\text { Coefficients } \\
\text { Beta }\end{array}$} & \multirow[b]{2}{*}{$t$} & \multirow[b]{2}{*}{ Sig. } \\
\hline & & B & Std. Error & & & \\
\hline \multirow[t]{3}{*}{1} & (Constant) & 8.119 & 8.685 & & .935 & .393 \\
\hline & Efikasi Diri & .616 & .607 & .380 & 1.014 & .357 \\
\hline & Kerumitan & .784 & .678 & .433 & 1.156 & .300 \\
\hline
\end{tabular}

Sumber : (Goldie Gunadi \& Sudaryana, 2020)

Gambar 16 Tabel Koefisien Variabel Independen

Terhadap Persepsi Persepsi Kemudahan Penggunaan

Persamaan regresi linier berganda :

$$
\mathrm{Y}=(8.119)+(0,616) \mathrm{X}_{1}+(0,784) \mathrm{X}_{2}
$$

Uji F

Pengujian hipotesa $\mathrm{H} 9$

Tabel 23. Tabel Hipotesa H9

\begin{tabular}{cl}
\hline Kode & \multicolumn{1}{c}{ Hipotesa } \\
\hline Ho & $\begin{array}{l}\text { Efikasi Diri dan Kerumitan secara bersama- } \\
\text { sama tidak berpengaruh terhadap Persepsi }\end{array}$ \\
& Kemudahan Penggunaan \\
Ha & $\begin{array}{l}\text { Efikasi Diri dan Kerumitan secara bersama- } \\
\text { sama berpengaruh terhadap Persepsi }\end{array}$ \\
& Kemudahan Penggunaan
\end{tabular}

Sumber : (Goldie Gunadi \& Sudaryana, 2020)

Nilai F hitung : 2,668

$\mathrm{F}$ tabel $=\mathrm{F}(2,6)=5,14$

F hitung $(2,668) \leq F$ tabel $(5,14)$ maka Ho diterima.

Nilai signifikansi penggaruh Efikasi Diri dan Kerumitan secara bersama-sama tidak berpengaruh terhadap Persepsi Kemudahan Penggunaan sebesar $0,163(>0,05)$ yang artinya Ho diterima.

Jadi dapat disimpulkan bahwa Efikasi Diri dan Kerumitan secara bersama-sama tidak berpengaruh terhadap Persepsi Kemudahan Penggunaan.

Uji t

Pengujian hipotesa $\mathrm{H} 10$

Tabel 24. Tabel Hipotesa H10

\begin{tabular}{cl}
\hline Kode & \multicolumn{1}{c}{ Hipotesa } \\
\hline Ho & $\begin{array}{l}\text { Efikasi Diri secara parsial tidak berpengaruh } \\
\text { terhadap Persepsi Kemudahan Penggunaan }\end{array}$ \\
Ha & $\begin{array}{l}\text { Efikasi Diri secara parsial berpengaruh } \\
\text { terhadap Persepsi Kemudahan Penggunaan }\end{array}$
\end{tabular}

Sumber : (Goldie Gunadi \& Sudaryana, 2020)

Nilai thitung : 1,014

$\mathrm{t}$ tabel $=\mathrm{t}(0,025,5)=2,571$

$t$ hitung $(1,014) \leq t$ tabel $(2,571)$ maka Ho diterima.

Nilai signifikansi penggaruh Efikasi Diri secara parsial terhadap Persepsi Kemudahan Penggunaan sebesar 0,357 $(>0,05)$ yang artinya Ho diterima.

Jadi dapat disimpulkan bahwa Efikasi Diri secara parsial tidak berpengaruh terhadap Persepsi Kemudahan Penggunaan.

Pengujian hipotesa H11

Tabel 25. Tabel Hipotesa H11

\begin{tabular}{cl}
\hline Kode & \multicolumn{1}{c}{ Hipotesa } \\
\hline Ho & $\begin{array}{l}\text { Kerumitan secara parsial tidak berpengaruh } \\
\text { terhadap Persepsi Kemudahan Penggunaan } \\
\text { Kerumitan secara parsial berpengaruh } \\
\text { terhadap Persepsi Kemudahan Penggunaan }\end{array}$ \\
Ha & Sumber : (Goldie Gunadi \& Sudaryana, 2020) \\
Nilai thitung : 1,156 \\
t tabel $=\mathrm{t}(0,025,5)=2,571$ \\
t hitung $(1,156) \leq \mathrm{t}$ tabel $(2,571)$ maka Ho diterima. \\
Nilai signifikansi penggaruh Kerumitan secara \\
parsial terhadap Persepsi Kemudahan Penggunaan \\
sebesar $0,300(>0,05)$ yang artinya Ho diterima.
\end{tabular}


Jadi dapat disimpulkan bahwa Kerumitan secara parsial tidak berpengaruh terhadap Persepsi Kemudahan Penggunaan.

\section{KESIMPULAN}

Dari hasil uji validitas, setiap item pernyataan dari masing-masing indikator dinyatakan valid. Setiap item pernyataan memiliki tingkat reliabilitas yang tinggi dengan nilai Cronbach's Alpha diatas 0,8. Hal ini berarti kuesioner yang digunakan pada penelitian ini memiliki tingkat konsistensi yang baik. Analisa data kuesioner dengan metode regresi linier berganda menyatakan bahwa Intensi Penggunaan memiliki pengaruh yang dignifikan terhadap Penggunaan Teknologi Sesungguhnya dengan nilai signifikansi 0,012. Persepsi Kegunaan dan Persepsi Kemudahan Penggunaan secara bersama-sama memiliki pengaruh yang dignifikan terhadap Intensi Penggunaan dengan nilai signifikansi 0,003. Persepsi Kegunaan juga secara parsial berpengaruh terhadap Intensi Penggunaan dengan nilai signifikansi sebesar 0,020. Sementara Persepsi Kemudahan Penggunaan tidak berpengaruh terhadap Intensi Penggunaan. Persepsi Kemudahan Penggunaan, Efikasi Diri dan Kerumitan secara bersama-sama memiliki pengaruh yang cukup signifikan terhadap Persepsi Kegunaan dengan nilai signifikansi 0,044. Namun, baik Persepsi Kemudahan Penggunaan, Kerumitan dan juga Efikasi Diri tidak berpengaruh secara parsial terhadap Persepsi Kegunaan.

1. Efikasi Diri dan Kerumitan baik secara bersamasama maupun parsial tidak berpengaruh terhadap Persepsi Kemudahan Penggunaan

\section{DAFTAR PUSTAKA}

Aprilia, K., \& Ghozali, I. (2013). Teknik penyusunan skala likert (summated scales) dalam penelitian akuntansi dan bisnis. Universitas diponegoro.

Bahar, A. (2019). Mengenal Scratch, Aplikasi Pemrograman Berbasis Visual untuk Membuat Permainan, Animasi, Kuis Interaktif Secara Mudah. www.Ahzaa.Net. https://www.ahzaa .net/2019/10/mengenal-scratch-aplikasi-pemrogra man.html
Budiarti, Y., \& Risyanto, R. (2020). Implementasi Metode Extreme Programming Untuk Merancang Sistem Informasi Pendaftaran Siswa Baru Berbasis Web Pada Smk Multimedia Mandiri Jakarta. Jurnal Informatika, 8(1), 1-9. https://doi.org/10.36987/informatika.v8i1.1402

D.Davis, F., \& Venkatesh, V. (1996). A critical assessment of potential measurement biases in the technology acceptance model: three experiments. International Journal of Human-Computer Studies, 45(1), 1996.

Duwi Priyatno. (2018). SPSS Panduan Mudah Olah Data Bagi Mahasiswa \& Umum. Penerbit ANDI.

Goldie Gunadi, \& Sudaryana, I. K. (2020). Analisa Tingkat Penerimaan Aplikasi Scratch Menggunakan Technology Acceptance Model (TAM) (Studi Kasus : PT. Bangun Satya Wacana).

HM, J. (2008). Sistem informasi keperilakuan (Edisi Revisi). Penerbit Andi.

Nikola Marangunić \& Andrina Granić. (2015). Technology Acceptance Model: A Literature Review From 1986 to 2013. Universal Access in the Information Society.

PT Bangun Satya Wacana. (n.d.). About Diginusa. Retrieved April 3, 2021, from http://www.diginusa.com/\#: :text=Diginusa adalah Departemen dari PT,panjang dan customer yang loyal.

Sekaran, U. (2006). Research Methods For Business: A Skill Building Approach (4th ed.). Wiley India Pvt. Limited.

Suharwoto, G. (2020). Pembelajaran Online di Tengah Pandemi Covid-19, Tantangan yang Mendewasakan. Timesindonesia.Co.Id. https://www.timesindonesia.co.id/read/news/261 667/pembelajaran-online-di-tengah-pandemicovid19-tantangan-yang-mendewasakan

Susanto, H. (2019). Pemrograman Scratch. Aswaja Pressindo. 
